\title{
A Concise Research Agenda for Environmental Law
}

\author{
J. E. Viñuales \\ University of Cambridge \\ jev32@cam.ac.uk
}

If one could truly select a number of directions where research on environmental law, including its international dimensions, should focus in the future, the selection process would have to be based not only on an understanding of the state of the discipline, but more generally on an assessment, or at least a reasoned and informed opinion, of the state of the challenges faced by the discipline. And such challenges could not be more important or pressing than they are now. The terminology used to characterize such challenges varies, much like the examples, which abound, from catastrophic climate change or the sixth massive species extinction to the more mundane and humanly understandable air, water and soil pollution. Importantly, the sum of these impacts and their analysis as the combined human geological influence on the Earth System can now rely on the specific terminology of the Anthropocene, i.e. the proposed new epoch of the Geological Time Scale where humans are the defining force. ${ }^{1}$

Thus characterized, the challenge (the advent of the Anthropocene) and its various manifestations (from climate change to pollution) call, in my view, for two levels of responses, which, in turn, suggest relatively clear directions of research. The first and more basic level of response is the need to move from words to action. Environmental law, including international environmental instruments, is by now a very developed body of law. But it still suffers greatly from an implementation deficit, particularly on the international plane. ${ }^{2}$ As I shall discuss in section I of this short essay, research on environmental

1 Although the concept of Anthropocene has deep historical roots, its recent introduction must be traced back to two influential articles: Paul Joseph Crutzen, Eugene Stoermer, 'The « Anthropocene »' IGBP Global Change Newsletter, 41 (2000), p. 17; P. J. Crutzen, 'Geology of Mankind', Nature, 415 (2002), p. 23.

2 See Jorge E. Viñuales, 'The Rise and Fall of Sustainable Development', Review of European, Comparative and International Environmental Law (RECIEL), 22 (2013), pp. 3-11.

(C) VIÑUALES, 2018 | DOI 10.1163/23527072-00101009

This is an open access article distributed under the terms of the prevailing CC-BY license at the time of publication. 
law can contribute to better implementation. The second and still poorly understood level is far more fundamental. At the risk of generating resistance from some readers, one may characterize environmental law as the law of negative externalities. By that, I understand that environmental law has historically been built as an additional layer of regulation applied to otherwise fully organized transactions, which rely on the laws relating to economic freedoms, business organization, labor, finance, investment and trade. If a negative externality is understood as the adverse effects of a transaction on parties who do not participate in such transaction, then environmental law is the additional layer introduced to address the externalities whereas the other strands of law mentioned above govern, indeed constitute the transaction itself. ${ }^{3}$ As I shall discuss in section II, understanding the role of law in the advent of the Anthropocene suggests the need to move beyond the mere regulation of externalities, i.e. beyond environmental law as we now know it, and tackle the core of the transactions themselves, those transactions at the roots of the thermo-industrial civilization.

Let me now elaborate on each of these two levels and highlight the directions for legal research that I see arising from each of them.

Implementation is an empirical matter, which is better addressed through the use of methods that are not at the center of legal research proper. A variety of empirical methods from surveys to econometric techniques to simulation modelling can be used to predict, monitor and assess the level of implementation of certain environmental laws and regulations.

Yet, this is not the province of lawyers or, more specifically, lawyers may be able to use such methods ${ }^{4}$ but they have no specific professional skill, let alone any comparative advantage, in making use of them as compared to other social scientists and modelling experts. The advantage of lawyers lies elsewhere, namely in the ability to understand the set of social practices we call law or legal systems. Forsaking this domain of legal research, however important other

3 See J. E. Viñuales, The Organization of the Anthropocene. In Our Hands? (The Hague: Brill Research Perspectives, 2018).

4 See e.g. Dave Owen and Caroline Noblet, "Interdisciplinary Research and Environmental Law", Ecology Law Quarterly, 41 (2015), pp. 887-938. 
methods may be, would not help with the implementation of environmental law and even less with the training of new generations.

Thus, at the outset, one must note that the extension of the methodological skill-set of lawyers, while very welcome and important, should not be at the expense of the skill-set proper to lawyers, as it has sometimes been the case in the proliferation of purported and often short-lived 'turns' to this or that methodology in legal research, which is more driven by career strategies than by thoughtful and dispassionate reflection of what would be a useful addition to knowledge. Law is a technology and if lawyers forgo its study no one else will take it up.

\section{$2 \quad$ Revisiting and Consolidating the Foundations}

The clarification in the previous section serves as a prelude to an unintuitive observation regarding what legal research can do to promote and strengthen implementation. As most academics with some exposure to practice (whether private practice, government work, civil society campaigning, etc.) will know, over-sophistication may hinder rather than help practical implementation. This is particularly true in environmental law, the operation of which is complex, sometimes obscure and even arcane. It is for this reason that, despite the many decades of environmental law scholarship, I still believe that much remains to be done in the clarification of the foundations of environmental law. By such foundations I refer to three main areas, although these are by no means the only foundational areas that would benefit from further research: (i) clarification of the architecture and inner structure of environmental legal systems; (ii) clarification of the principles of (international) environmental law; and (iii) clarification of the embeddedness of (international) environmental law within (international) law.

Clarifying structure is not a mere exercise of style. In a 2012 report from the UK Environmental Law Association, the lack of a clear structure in the environmental law of the UK was seen as a major shortcoming to be addressed in order to improve implementation, ${ }^{5}$ and this situation is not likely to improve after 'Brexit'. This is also a major problem on the international plane, where international environmental law is still taught as a collection of unrelated (or at best loosely related) topics juxtaposed one after the other without any unifying conceptual architecture. Compared to other 'branches' of international law,

5 See the study by the U Environmental Law Association: UKELA, "The State of UK Environmental Legislation in 2011-2012', available at www.ukela.org,accessed on 6 April 2018. 
such as trade or investment law, the structure of which is simpler and more clear-cut, international environmental lawyers tend to be on shakier grounds as they lack the ability to mobilize the big picture of environmental law and bring it to bear on specific points. There are several structural frames that could be used to clarify the architecture of domestic, European and international environmental law, including a distinction between transversal regulation and sectorial regulation, ${ }^{6}$ the identification of modular components underpinning environmental legal systems, ${ }^{7}$ or the organization of different levels of environmental regulation in a pyramidal structure. ${ }^{8}$ These are just some of the examples that I have used in my own work and that others have used in theirs. ${ }^{9}$ They suggest that many options are possible and useful for different purposes. The main point is, of course, not to advocate for the use of one or the other analytical approach but, much more importantly, to emphasize the importance of paying attention to structure, to keep the wood in sight while exploring the trees.

The clarification of the principles of (international) environmental law is of critical importance for implementation. Principles are normally formulated

6 See J. E. Viñuales and Emma Lees, 'Environmental and Energy Law as a Field of Research: A Structural Overview', in J. E. Viñuales and E. Lees (eds.), Environmental and Energy Law Vol I: International Dimensions, Vol II: European Dimensions, Vol III: Transnational, Comparative and Domestic Dimensions (Cheltenham: Edward Elgar, forthcoming 2017) (introducing a transversal/sectorial structure); and E. Lees and J. E. Viñuales (eds.), The Oxford Handbook on Comparative Environmental Law (Oxford University Press, forthcoming 2018) (both relying on a modular or systems-based structure).

7 Jody Freeman and Daniel A. Farber, 'Modular Environmental Regulation', Duke Law Journal, 54 (2005), p. 795 .

8 Pierre-Marie Dupuy and J. E. Viñuales, International Environmental Law (Cambridge University Press, $2^{\text {nd }}$ ed. 2018), chapter 3 .

9 See for instance, a historical framework in Edith Brown Weiss, "The Evolution of International Environmental Law", Japanese Yearbook of International Law, 54 (2011), pp. 1-27; for a third world approach to international law applied to environmental law, see Sumudu Atapattu and Carmen G. Gonzalez, "The North-South Divide in International Environmental Law: Framing the Issues", in Shawkat Alam, Sumudu Atapattu, Carmen G. Gonzalez and Jona Razzaque (eds), International Environmental Law and the Global South (Cambridge University Press, 2015), pp.1-20; for a theory of sources of international environmental law, see Ved P. Nanda and George Pring, International Environmental Law and Policy for the $27^{\text {st }}$ century (Martinus Nijhoff Publishers, 2013), pp. 6-18; for a decision-making approach, see David A Wirth, 'Reexamining Decision-Making Processes in International Environmental Law', Iowa L Rev 79/4: 769-802 (1994). 
in international, ${ }^{10}$ constitutional ${ }^{11}$ and/or framework instruments, ${ }^{12}$ and they therefore possess a wide scope of application. If principles remain vague or foggy, the potential of their far-reaching scope remains unrealized. ${ }^{13}$ Conversely, once their contours and operation become better understood and tested in litigation and administrative practice, their authority grows exponentially. This is particularly important due to the relatively recent introduction of environmental principles in constitutions around the world and international instruments, with the oldest such formulations dating back to the late 196os. Yet, many principles remain poorly understood as well as over-debated. Two major examples of the extent to which over-sophistication may hinder rather than promote implementation are arguably given by the precautionary approach/ principle and the sustainable development concept/principle. Both have benefited from significant contributions, ${ }^{14}$ which have clarified their scope.

10 See for instance, A. Epiney and M. Scheyli, Strukturprinzipien des Umweltvölkerrechts (Baden-Baden: Nomos, 1998); Laurence Boisson de Chazournes and Sandrine MaljeanDubois, 'Les principes du droit international de l'environnement', in Juris-classeur environnement, fascicule 146-15 (2011); J. E. Viñuales (ed.), The Rio Declaration on Environment and Development. A Commentary (Oxford University Press, 2015).

11 See particularly, in the German constitutional scholarship, the works of R. Steinberg, Der ökologische Verfassungsstaat (Frankfurt am Main: Suhrkamp, 1988) (arguing for an 'ecological constitutional State' in which protection of the environment is both instrumental and an end in itself); D. Boyd, The Environmental Rights Revolution. The Environmental Rights Revolution: A Global Study of Constitutions, Human Rights, and the Environment (Vancouver: UbC Press, 2011); J. R. May, E. Daly, Global Environmental Constitutionalism (Cambridge University Press, 2014).

12 See generally, E. Scotford, Environmental Principles and the Evolution of International Law (Oxford: Hart, 2017); and N. de Sadeleer, Environmental Principles: From Political Slogans to Legal Rules (Oxford University Press, 2002).

13 This consideration is driving the recent initiative by the French government to conclude a Global Environment Pact. See the website of the Club de Juristes: http://www.leclubdesjuristes.com/vers-un-pacte-mondial-pour-l-environnement-programme/, accessed on 21 September 2017.

14 On the precautionary principles/approach see among many others: David Freestrone and Ellen Hey (eds.), The Precautionary Principle and International Law. The Challenge of Implementation (The Hague: Kluwer, 1996); Arie Trouwborst, Evolution and Status of the Precautionary Principle in International Law (Springer, 2002); Jacqueline Peel, The Precautionary Principle in Practice: Environmental Decision-making and Scientific Uncertainty (Sydney: Federation Press, 2005); Caroline Foster, Science and the Precautionary Principle in International Courts and Tribunals (Cambridge University Press, 2011). On the sustainable development see among many others: Virginie Barral, Le développement durable en droit international: Essai sur les incidences juridiques d'une norme evolutive (Brussels: 
But their very polysemy and the existence of wide debates over their specific contents and requirements have limited the practical power of these principles, either as a result of mere doubt in the minds of (over-cautious) adjudicators or of deliberate attempts at blurring their contents (e.g. through so-called 'green-washing') by adversely affected industries. When it comes to legal research on principles, less is probably more or, in other words, more modest research on the specific contours, reception and operation of principles can achieve more than over-sophisticated theorizing about them.

My point on principles is also applicable to the question of embeddedness. Labels such as 'environmental' law may be useful for pedagogical (designing a degree, a course, a textbook, a journal, etc.), career specialization (defining a chair, an area of research, a practice area in a law firm or another organization, etc.), or even sociological (designing a community or an organization within a governmental structure). But, technically, they have a very limited legal existence (e.g. a specific interpretation technique may apply to norms considered to be encompassed by the descriptive label 'environmental law'). The same is true for other such labels (e.g. trade law, investment law, etc.). A proper understanding of this point is a pre-condition to avoiding utterly artificial legal problems, such as the chimera that the trade or the investment 'regime' collide with the environmental 'regime'. There may certainly be tensions from a sociological perspective, and the interactions between treaties or norms governing trade or investment transactions and norms requiring States to take certain measures to protect the environment can and must be studied. But, from a legal standpoint, such approaches must not overlook or overshadow the more specifically legal analysis focusing on the interaction between norms, treaty sections, treaties and legally-linked systems of treaties. ${ }^{15}$ As practitioners know, overlooking a key provision when providing legal advice can generate professional liability and the fact that such provision belongs to a different 'branch' of law would not necessarily help. Lawyers and legal researchers must take into account all the norms that are relevant to a given question or problem. It is only by understanding the limitations of a conceptual tool such as that of 'regime' or 'branch' that such tools can be properly used, for example, to refer more easily to a set of rules and practices that have some sociological or cultural unity. But the analysis of embeddedness must go much further and take into account also

Bruylant, 2015); Christina Voigt, Sustainable Development as a Principle of International Law (Leiden: Martinus Nijhoff, 2008).

15 See J. E. Viñuales, 'Cartographies imaginaires: Observations sur la portée juridique du concept de 'régime spécial' en droit international', Journal du droit international (Clunet), 140 (2013), p. 405. 
the legal interconnections between different relevant norms, irrespective of the 'branches' or 'regimes' to which they purportedly 'belong'. Otherwise, (international) 'environmental' law will still be artificially treated as 'external' and played down, with real effects for the implementation of environmental law.

The three directions of research suggested in this section are by no means the only ones relevant for the challenge of implementation, but they are at present overlooked despite their (in my opinion higher) importance (as compared to other (formerly) fashionable questions, such as fragmentation, methodological 'turns', etc. This said, in the three cases, they remain within a conceptual frame that is inherently limiting for the protection of the environment, namely that of environmental law as an 'additional' layer that intervenes once that core transactions (production processes, investments, trade) have been fully organized by other arrays of norms. In what follows, I go beyond this conceptual frame and hence beyond environmental law as it is presently understood, and I look at the role of law in the Anthropocene.

\section{Law and the Anthropocene}

Lawyers are latecomers to the integrative research program encompassing humanities, social and natural sciences. Although a number of significant contributions have been made that seek to understand the role of law in the Anthropocene, they tend to maintain the environmental law conceptual frame discussed above or be concerned with implications in one specific legal context. Moreover, even when more foundational questions are addressed, interest in this line of research has so far been limited to a handful of well-known experts. ${ }^{16}$ To escape the traditional conceptual mindset and move away from

16 See Ahjond S. Garmestani, Craig R. Allen (eds.), Social-Ecological Resilience and Law (New York: Columbia University Press, 2014); L. Kotze, Global Environmental Constitutionalism in the Anthropocene (Oxford: Hart Publishing, 2016); Yearbook of International Environmental Law (2014) 25 (1); Nicholas Robinson, 'Beyond Sustainability: Environmental Management for the Anthropocene Epoch', Journal of Public Affairs, 12 (2012), p. 181; Nicholas Robinson, 'Fundamental Principles of Law for the Anthropocene ?', Environmental Policy and Law, 44 (2014), p. 1; Eric Biber, 'Law in the Anthropocene Epoch', uc Berkeley Public Law Research Paper No. 2834037, (2 September 2016); Louis Kotzé, 'Rethinking Global Environmental Law and Governance in the Anthropocene', Journal of Energy and Natural Resources Law, 32 (2012), p. 121; Louis Kotzé, 'Human Rights and the Environment in the Anthropocene' The Anthropocene Review, 1 (2014), p. 1; Klaus Bosselmann: K. Rakhyun and K. Bosselmann, 'International Environmental Law in the Anthropocene: Towards a Purposive System of Multilateral Environmental Agreements', Transnational Environmental 
a focus on externalities, however monstrous (mainstream economic theory still treats climate change as a mere negative externality and one can suppose that the same misperception would apply to the advent of the Anthropocene), research on a broader set of questions is needed. Such research effort must be integrative (address the same broad questions as other disciplines), mobilize legal analysis proper (whether together with other methods or not), and identify a discreet set of research questions that meet the two previous criteria (relevant for other disciplines and importance of legal analysis proper for their elucidation). On this basis, I would like to propose three main directions for legal research. ${ }^{17}$

The first research direction concerns a broader inquiry of great importance for other disciplines, namely the fact that the Anthropocene narrative challenges the so-called ontological dualism thesis, i.e. the widely held assumption that human progress consists of pushing back natural frontiers and constraints, within a natural theatre deemed to be immutable in a human timeframe. ${ }^{18}$ Such frontiers have been seen as less and less relevant for the understanding of human activity as science and technology - hence human powers over nature - progressed. Instead, the Anthropocene narrative suggests that human and natural histories are intertwined, even within a short human - timeframe, because what was believed to be progress with no adverse impact on the ability of the Earth System to regenerate is in fact modifying major geological cycles to such an extent that humans are a geological force whose impact on the Earth will be felt both in natural cycles and by humans themselves. Within this broader inquiry a cluster of legal questions can be identified regarding: (i) the extent to which and the processes whereby law and legal concepts have been detached from nature, ${ }^{19}$ and the implications for the

Law, 2 (2013), p. 285; D. Vidas, O. K. Fauchald, Ø. Jensen, M. W. Tvedt, 'International law for the Anthropocene ? Shifting perspectives in regulation of the oceans, environment and genetic resources', Anthropocene, 9 (2015), p. 1.

17 The formulation of these question relies on Viñuales, above n. 3.

18 See Dipesh Chakrabarty, 'The climate of history: four theses', Critical Inquiry, 35 (2009), p. 197 .

19 Through the emergence and diffusion of legal positivism, usually traced back to the work of J. Austin, The Province of Jurisprudence Determined (London: John Murray, 1832). Legal positivism is traditionally understood as having emerged with the philosophical work of Jeremy Bentham (Of Laws in General, London: Athlone Press, 1970 [1782]), influenced by the works of David Hume and Thomas Hobbes, and influencing Austin and his conception of 'command'. Two different conceptions of legal positivism which have exercised immense influence over the twentieth century are those of Hans Kelsen (Reine Rechtslehre: Einleitung in die rechtswissenschaftiche Problematik (Leipzig; Wien: F. Deuticke, 1934)) 
advent, sustaining and potential management of the Anthropocene; ${ }^{20}$ (ii) the extent to which law and legal concepts can express the unprecedented level of responsibility of humans as a geological force driving the Anthropocene; ${ }^{21}$ and (iii) the extent to which legal orders can be adjusted through additional layers of norms - such as environmental law - or, instead, require a deeper reformulation of foundational concepts, with the ensuing imbrications of such reformulations, to address the challenges of the Anthropocene. ${ }^{22}$

The second broader inquiry relates to inequalities within humans. Stating that 'humans' are the geological force behind the Anthropocene conceals profound intra-species inequalities between regions and groups of people in prompting, sustaining or suffering from the unsettling of natural cycles unveiled by the Anthropocene narrative. ${ }^{23}$ Understanding such inequalities is important both for allocating responsibilities and for addressing the social dynamics that prompted and sustained the Anthropocene and that have affected and will, in all likelihood, affect some groups more than others. Within this broader inquiry a cluster of legal questions can be identified regarding: (i) the relation between a certain legal organization of production - including the law governing business organization, ${ }^{24}$ labor relations, ${ }^{25}$ and effects on third

and Herbert Hart (The Concept of Law (Oxford: Clarendon Press, 1961)); Hans Kelsen, General Theory of Law and the State (Cambridge MA: Harvard University Press, 1945).

The relation between a certain form of law (described and designed by legal positivism) and the rise of capitalism has been analysed by Max Weber, Economy and Society. An Outline of Interpretive Sociology (Berkeley: University of California Press, edn by G. Roth \& R. Wittich, 1968), part II, section VIII: Economy and Law (The Sociology of Law), pp. 641ff. On this question seen from the perspective of ethics see Hans Jonas, In Search of an Ethics for the Technological Age (Chicago IL: University of Chicago Press, 1984); and from the same author, 'Philosophy at the End of the Century: Survey of its Past and Future', Social Research, 61/4 (1994), p. 815.

See e.g. D. Grinlinton, P. Taylor (eds), Property Rights and Sustainability: The Evolution of Property Rights to meet Ecological Challenges (Leiden: Martinus Nijhoff, 2011) (the contributors to this edited volume offer a critical perspective on property rights as tool for environmental protection and discuss different adjustments and reformulations).

23 See A. Malm, A. Hornborg, 'The geology of mankind? A critique of the Anthropocene narrative' (2014) 1/1 The Anthropocene Review 62.

24 See e.g. H. Hansmann, R. Kraakman, R. Squire, 'Law and the Rise of the Firm' (2005/2006) 119 Harvard Law Review 1335.

25 See e.g. A. Supiot, Critique du droit du travail (Paris: Presses universitaires de France, 2007); M. Linder, The Employment Relationship in Anglo-American Law: A Historical Perspective (New York: Greenwood, 1989); J. Le Goff, Du silence à la parole. Une histoire du droit du travail des années 1830 à nos jours (Rennes: Presses universitaires de Rennes, 2004). 
parties $^{26}$ - and the inequalities underpinning the Anthropocene; (ii) the relation between the law governing exchange systems at the internal (including imperial) or international (bilateral, regional, global) levels ${ }^{27}$ and the processes prompting and sustaining the Anthropocene; and (iii) how law can be used to allocate responsibilities for the past, present and future adverse impacts ${ }^{28}$ unveiled by the Anthropocene narrative among past, present and future groups of people.

The third broader inquiry concerns the process of socio-technical transition. Given the role of energy, transportation, agriculture and other foundational activities in prompting and sustaining the Anthropocene, it is necessary to understand the dynamics of transitions to other socio-technical regimes, including the emergence of pioneering technologies, the necessary period for their refinement and diffusion, the many resistances from prior entrenched interests and, more generally, the many trade-offs entailed by the transition. ${ }^{29}$ Within this broader inquiry a cluster of legal questions can be identified regarding: (i) ways to improve law and regulation as a technology to address the challenges of the Anthropocene; ${ }^{30}$ (ii) ways in which law can promote or, conversely, hinder attempts to transition from one unsustainable socio-technical

26 See e.g. J. F. Brenner, 'Nuisance Law and the Industrial Revolution' (1974) 3/2 Journal of Legal Studies 403; A. E. Dingle, 'The Monster Nuisance of All. Landowners, Alkali Manufacturers, and Air Pollution, 1828-1864' (1982) 35/4 Economic History Review 529; B. Pontin, 'Tort Law and Victorian Government Growth: the historiographical significance of tort law in the shadow of chemical pollution' (1998) 18/4 Oxford Journal of Legal Studies 661.

27 The history of trade law has focused mostly on the post-1945 system, for which there are many accounts. For the earlier period, one account paying close attention to legal aspects is provided by Noris Bolde, 'Droit et technique des traités de commerce' (1924) 3 Recueil des cours de l'Académie de droit international de La Haye 291.

28 On allocation between groups belonging to present generations see Philippe Cullet, 'Principle 7: Common but Differentiated Responsibilities', in J. E. Viñuales (ed.), The Rio Declaration on Environment and Development. A Commentary (Oxford University Press, 2015), pp. 229-244. On intergenerational equity see E. Brown Weiss, In Fairness to Future Generations: International Law, Common Patrimony and Intergenerational Equity (United Nations University, 1989) and J. C. Tremmel (ed.), Handbook of Intergenerational Justice (Cheltenham: Edward Elgar, 2006), pp. 187-216.

29 See A. Grubler, 'Energy transitions research: Insights and cautionary tales', Energy Policy, 50 (2012), p. 8.

30 See e.g. A. S. Garmestani, C. R. Allen (eds.), Social Ecological Resilience and Law (New York: Columbia University Press, 2014). 
regime to a sustainable one ${ }^{31}$; and (iii) legal ways of reflecting value choices or of organizing processes to legitimize the choices entailed by such a transition. ${ }^{32}$

These and other questions take a much broader look at law. Although the answers to these research questions would necessary have to rely, to some extent, on legal analysis proper, other methods and disciplines may be necessary to understand the operation of law in prompting, sustaining and potentially managing the Anthropocene. At the same time, the type of legal research involved would very clearly exceed the narrow confines of environmental law. Instead, it would be about the role of law as a whole in governing human action of increasingly clear geological proportions.

\section{Concluding Remarks}

Overall, this concise research agenda for environmental law relies on a distinction between mitigating the negative environmental externalities of a transaction and tackling the legal organization of the transaction as such.

Environmental law focuses predominantly on the first term of the distinction. In this context, I submit that three main research directions should be further explored: the structure of environmental law, its main foundational principles, and its embeddedness within the broader legal order.

The second term of the distinction emphasizes the need to go beyond a focus on negative externalities and investigate the governance of the underlying transactions, essentially production processes. In this context, I call for further research on three main clusters of questions, which concern the legal dimensions of the so-called ontological dualism thesis, intra-species inequalities in the advent of the Anthropocene, and socio-technical transitions.

Above all, what I would like to emphasize is the need to find a vantage point that rather than zooming in on the research object attempts to zoom out; to take a step - perhaps a few steps - back and try to understand environmental law as a technology, with its many strengths but also limitations.

31 See e.g. Jorge E. Viñuales, Foreign Investment and the Environment in International Law (Cambridge University Press, 2012).

32 See e.g. Jonas Ebbesson, 'Principle 10: Public Participation', in J. E. Viñuales (ed.), The Rio Declaration on Environment and Development. A Commentary (Oxford University Press, 2015), pp. 287-310. 